\title{
APLIKASI DATA PENGINDERAAN JAUH UNTUK KAJIAN KONDISI EKSISTING EKOSISTEM MANGROVE DI WILAYAH KEPESISIRAN KECAMATAN PANTAI LABU, KABUPATEN DELI SERDANG, SUMATERA UTARA
}

\author{
Eni Yuniastuti ${ }^{1}$, Anik Juli Dwi Astuti ${ }^{1}$, Dwi Wahyuni Nurwihastuti ${ }^{1}$ \\ 1Jurusan Pendidikan Geografi, Fakultas Ilmu Sosial, Universitas Negeri Medan \\ Jl. Willem Iskandar Psr V Medan Estate Medan, 20211 Indonesia \\ Email: eni.yuniastuti17@gmail.com
}

\begin{abstract}
Abstrak
Penelitian ini dilaksanakan di wilayah kepesisiran Kecamatan Pantai Labu, Kabupaten Deli Serdang, Sumatera Utara. Penelitian ini bertujuan untuk mengetahui kondisi eksisting, mengetahui indeks keanekaragaman, dan mengetahui agihan ekosistem mangrove yang tumbuh di wilayah kepesisiran Kecamatan Pantai Labu. Penelitian ini menggunakan metode survei. Metode pengumpulan data dengan sampling serta metode analisisnya secara kualitatif. Populasi dari penelitian ini adalah seluruh ekosistem mangrove yang terdapat di daerah penelitian. Teknik pengambilan sampel dengan cara purposive sampling untuk penentuan transek garis dan petak contoh (transect line plot). Teknik pengumpulan data meliputi analisis data sekunder, observasi, dan perhitungan langsung di lapangan. Variabel penelitian ini meliputi kerapatan (densitas), kekerapan (frekuensi), luas penutupan (coverage), indeks nilai penting (importance value index), indeks dominasi (index of dominance), dan indeks keanekaragaman (diversity). Teknik analisis hasil menggunakan analisis spasial dan analisis deskriptif. Hasil penelitian menunjukkan kondisi eksisting ekosistem mangrove yang terdapat di Kecamatan Pantai Labu berdasarkan hasil interpretasi visual citra Google Earth Tahun 2015 sebesar 517,95 ha. Keanekaragaman vegetasi mangrove di Kecamatan Pantai Labu memiliki indeks keanekaragaman $H^{\prime}<1,0$. Artinya keanekaragaman mangrove di Kecamatan Pantai Labu masih rendah, miskin, produktivitas sangat rendah sebagai indikasi adanya tekanan yang berat, dan ekosistem tidak stabil. Spesies mangrove yang terdapat di Kecamatan Pantai Labu meliputi Avicennia sp (api-api), Rhizophora sp (bakau), Sonneratia sp (pedada), Bruguira sp, dan Xylocerpus sp (nyirih). Persebaran dan agihan ekosistem mangrove di Kecamatan Pantai Labu berada di sepanjang tepi pesisir yang meliputi Desa Sungai Tuan dengan luas 128,58 ha, Desa Bagan Serdang dengan luas 78,75 ha, Desa Regemuk dengan luas 33,50 ha, Desa Pantai Labu Pekan dengan luas 15,85 ha, Desa Paluh Sebaji dengan luas 73,48 ha, dan Desa Denai Kuala dengan luas 187,79 ha.
\end{abstract}

Kata Kunci: ekosistem mangrove, wilayah kepesisiran, Google Earth

\section{PENDAHULUAN}

Indonesia merupakan salah satu negara yang mempunyai garis pantai yang panjang dan mempunyai keanekaragaman sumberdaya alam. Keanekaragaman sumberdaya alam ada yang di wilayah ekosistem darat dan ekosistem perairan. Ekosistem perairan di Indonesia terdiri atas berbagai macam, yaitu estuaria, padang lamun, terumbu karang, pulaupulau kecil, laut dalam, dan mangrove.
Ekosistem mangrove ini dapat ditemukan di seluruh kepulauan Indonesia. Kepulauan Indonesia yang mendominasi keberadaan ekosistem mangrove ini meliputi Pulau Papua, Pulau Kalimantan, Pulau Riau, dan Pulau Sumatera. Pulau Sumatera termasuk pulau yang besar di Indonesia yang mempunyai ekosistem mangrove yang cukup banyak. Keterdapatan hutan mangrove di Provinsi Sumatera Utara meliputi daerah 
Kabupaten Deli Serdang, Kabupaten Asahan, Kabupaten Labuan Batu, Kabupaten Tapanuli dan Kabupaten Nias (Tim Survei BPAP Balai Planologi Areal Pelestarian, dalam Yusnawati, 2004). Kabupaten Deli Serdang khususnya Kecamatan Pantai Labu ini yang dijadikan sebagai daerah penelitian. Kecamatan Pantai Labu yang mempunyai ekosistem mangrove dengan mata pencaharian penduduk sebagai nelayan meliputi Desa Sei Tuan, Desa Bagan Serdang, Desa Regemuk, Desa Paluh Sibaji, Desa Pantai Labu Pekan, dan Desa Denai Kuala.

Formasi atau susunan dari ekosistem mangrove merupakan perpaduan antara daratan dan lautan. Ekosistem mangrove sangat bergantung pada kadar salinitas, endapan debu (hasil sedimentasi), dan pasang surut air laut. Air laut yang naik (pasang) mempunyai fungsi untuk memberikan makanan, meningkatkan kadar salinitas untuk persyaratan tumbuh dan berkembangnya ekosistem mangrove.

Keterdapatan ekosistem mangrove di wilayah kepesisiran mempunyai manfaat yang sangat banyak. Manfaat dari keterdapatan ekosistem mangrove meliputi: (1) mangrove sebagai habitat plasma nutfah tumbuh dengan baik, (2) mangrove melindungi pantai dan sungai dari bahaya erosi, (3) mangrove dapat menahan hasil proses penimbunan lumpur sehingga membantu terbentuknya lahan baru, (4) mangrove dapat dijadikan greenbelt di sempadan pantai dan sungai, (5) penghasil kayu bakar dan bahan baku industri, serta (6) kawasan mangrove dapat dijadikan sebagai tempat wisata. Fungsi dan peran mangrove sangat beranekaragam, secara ekologis hutan mangrove mempunyai fungsi baik dari aspek fisik, aspek kimia, dan aspek biologi (Khakim, 2011). Fungsi ekologis hutan mangrove dari segi fisiknya sebagai pelindung pantai, penahan banjir genang pasang air laut, dan menyusun mekanisme hubungan antar komponen dalam ekosistem mangrove/ ekosistem lain. Fungsi ekologis hutan mangrove dari segi kimia berfungsi sebagai penyerap bahan pencemar, sumber energi bagi biota laut, dan suplai bahan organik dalam lingkungan perairan. Fungsi ekologis hutan mangrove dari aspek biologi dapat digunakan untuk menjaga kestabilan produktivitas dan ketersediaan sumberdaya hayati di perairan.

Manfaat dan fungsi ekosistem mangrove ini digunakan sebagai bahan pertimbangan bahwa konservasi dan perlindungan terhadap ekosistem mangrove harus di perketat. Perlindungan ekosistem mangrove dapat dimulai dari menjaga kelestarian dan keanekaragaman jenis ekosistem mangrove. Pentingnya mengetahui keanekaragaman jenis mangrove dapat digunakan sebagai acuan atau rekomendasi dalam pemanfaatan mangrove. Pemanfaatan dan pengelolaan ekosistem mangrove yang baik dan tepat dapat digunakan untuk meningkatkan tingkat pendapatan masyarakat di kawasan pesisir. Hal inilah yang melatarbelakangi dari penelitian ini.

Tujuan artikel ini akan dikemukakan tentang kondisi eksisting ekosistem mangrove yang terdapat di wilayah kepesisiran Kecamatan Pantai Labu, indeks keanekaragaman ekosistem mangrove di wilayah kepesisiran Pantai Labu, dan persebaran atau agihan spesies mangrove yang terdapat wilayah kepesisiran Kecamatan Pantai Labu.

\section{METODE PENELITIAN}

Penelitian ini dilakukan di sebagian wilayah kepesisiran Kecamatan Pantai Labu, Kabupaten Deli Serdang, Provinsi Sumatera Utara dan dilaksanakan pada Mei - Oktober 2015. Metode penelitian yang digunakan adalah metode survei. Metode pengumpulan data dengan sampling dan metode analisis secara kualitatif. Metode penelitian ini dilakukan dengan prosedur penelitian yang jelas, mencakup alat dan bahan, pengumpulan data, pengolahan dan analisis data, serta analisis hasil.

Alat yang dibutuhkan dalam penelitian ini adalah: komputer/ laptop untuk analisis data dan penulisan, printer 
untuk mencetak hasil dan laporan, perangkat Lunak Microsoft Word 2013 dan Perangkat Lunak Microsoft Excel 2013 untuk analisis dan penulisan, perangkat lunak ArcGIS 10.1 digunakan untuk pengolahan data berbasis sistem informasi geografi, GPS (Global Positioning System) digunakan untuk penentuan lokasi sampel di daerah penelitian, dan kamera digunakan untuk dokumentasi pada saat dilakukan survei lapangan. Alat untuk penelitian di lapangan, meliputi: meteran, alat tulis, yallon, tali rafia, serta perahu dan motor. Bahan yang dibutuhkan dalam penelitian ini adalah sebagai berikut: Peta Rupa Bumi Indonesia wilayah kepesisiran Kecamatan Pantai Labu skala 1: 250.000 Tahun 1986, peraturan PP tentang transek Keputusan Mentri Lingkungan Hidup nomor 201 tahun 2004, citra Google Earth daerah penelitian, dan buku identifikasi karakteristik dan jenis-jenis mangrove.

Teknik pengumpulan data yang digunakan dalam penelitian ini adalah analisis data sekunder, observasi, dan perhitungan di lapangan. Analisis data sekunder digunakan untuk mendukung dalam pembahasan dalam penelitian ini. Observasi dan perhitungan di lapangan digunakan untuk menentukan tingkat keanekaragaman ekosistem mangrove di daerah penelitian. Analisis hasil yang digunakan antara lain analisis spasial dan analisis deskriptif. Analisis spasial digunakan untuk menjelaskan secara keruangan kondisi eksisting mangrove yang menggunakan metode teknik penginderaan jauh dan persebaran mangrove yang terdapat di daerah penelitian. Analisis deskriptif digunakan untuk menjelaskan kondisi eksisting mangrove yang menggunakan metode deskripsi. Analisis deskriptif ini digunakan untuk mendeskripsikan komunitas ekosistem mangrove yang terdapat di daerah penelitian yang meliputi kerapatan (densitas), kekerapan/frekuensi, luas penutupan (coverage), indeks nilai penting (importance value index), indeks dominasi (index of dominance), dan indeks keanekaragaman (diversity).

\section{HASIL DAN PEMBAHASAN}

Hasil yang dicapai pada penelitian ini adalah keadaan saat ini/ kondisi eksisting ekosistem mangrove di wilayah kepesisiran Kecamatan Pantai Labu, Kabupaten Deli Serdang, Provinsi Sumatera Utara. Ruang lingkup dan sasaran utama penelitian ini adalah ekosistem mangrove yang terdapat di wilayah kepesisiran Kecamatan Pantai Labu. Deskripsi hasil penelitian ini diuraikan secara lengkap pada sub-subbab berikut ini.

\section{Kondisi Fisik Daerah Penelitian}

Kecamatan Pantai Labu secara geografis terletak di antara koordinat $2^{\circ} 57^{\prime}$ - $3^{\circ} 16^{\prime}$ LU dan $98^{\circ} 37^{\prime}-99^{\circ} 27^{\prime}$ BT, dan terdapat di kawasan Pantai Timur Sumatera Utara. Secara administratif batas wilayah Kecamatan Pantai Labu mempunyai batas-batas sebagai berikut sebelah utara berbatasan dengan Selat Malaka, sebelah timur berbatasan dengan Kecamatan Pantai Cermin dan Kabupaten Serdang Bedagi, sebelah selatan berbatasan dengan Kecamatan Beringin, dan sebelah Barat berbatasan dengan Kecamatan Batang Kuis/ Percut Sei Tuan.

Luas wilayah daerah penelitian di Kecamatan Pantai Labu ini berdasarkan Peta Rupa Bumi Indonesia sekitar 34.120 ha, yang meliputi enam desa yaitu Desa Sungai Tuan, Desa Bagan Serdang, Desa Regemuk, Desa Pantai Labu Pekan, Desa Paluh Sebaji, dan Desa Denai Kuala. Jumlah penduduk di Kecamatan Pantai Labu sekitar 45.440 jiwa, dan jarak dari ibu kota kabupaten berkisar $10 \mathrm{~km}^{2}$ (Badan Pusat Statistik, Kabupaten Deli Serdang Dalam Angka 2014).

Kecamatan Pantai Labu ini terletak di daerah tropis dan memiliki iklim sedang, suhu berkisar antara $23^{\circ} \mathrm{C}$ sampai dengan $34^{\circ} \mathrm{C}$. Kondisi iklim di daerah penelitian ini dikenal memiliki dua musim, yaitu musim kemarau dan musim penghujan. Kedua musim ini dipengaruhi 
oleh angin laut yang membawa hujan dan angin gunung yang membawa panas dan lembab. Musim kemarau biasanya terjadi pada bulan Juni sampai September, sedangkan musim penghujan terjadi pada bulan Desember sampai Maret. Menurut catatan Stasiun Klimatologi Sampali (dalam Kabupaten Deli Serdang Dalam Angka 2014), pada tahun 2013 terdapat rata-rata 17 hari hujan dengan volume curah hujan sebanyak rata-rata $187 \mathrm{~mm}$. Curah hujan paling banyak terjadi pada bulan Desember yaitu berkisar $489 \mathrm{~mm}$ dengan hari hujan sebanyak 22 hari, sedangkan curah hujan terkecil terjadi pada bulan Maret sebesar $74 \mathrm{~mm}$ dengan hari hujan 4 hari.

\section{Tipologi dan Dinamika Wilayah Kepesisiran Kecamatan Pantai Labu}

Berdasarkan survei awal, wilayah kepesisiran Kecamatan Pantai Labu termasuk pada wilayah kepesisiran landai dengan material di dominasi lumpur dengan proses utama sedimentasi lumpur dan pasang surut air laut, yang menunjukkan perkembangan wilayah berlumpur yang pesat. Lingkup wilayah kepesisiran pada daerah rataan pasang surut dimulai dari zona pecah gelombang (breakers zone), pantai (shore), rataan pasang surut, pesisir (coast), dan lahan buritan atau hinterland (dirumuskan berdasarkan konsep CERC, 1984; Pethick, 1984 dan Sunarto, 2001 dalam Sunarto, 2003).

Kondisi di wilayah kepesisiran Kecamatan Pantai Labu ada dua material penyusun yaitu material penyusun lumpur dan materi penyusun pasir (survei awal, September 2015).

Tipologi wilayah kepesisiran Kecamatan Pantai Labu ini termasuk dalam tipologi pesisir primer akibat deposisional sub-arial (sub-areal deposition coast). Menurut Gunawan et al. (2005), subareal deposition coast adalah pesisir yang terbentuk akibat akumulasi secara langsung bahan-bahan sedimen sungai, glacial, angin atau akibat longsor lahan ke arah laut. Wilayah kepesisiran Kecamatan Pantai Labu jika ditinjau berdasarkan sudut lereng pantai yang terbentuk dapat dikategorikan menjadi wilayah kepesisiran datar. Wilayah kepesisiran datar/hampir datar mempunyai sudut kemiringan lereng 0-2\% (van Zuidam and van Zuidam-Cancelado, 1978).

\section{Kondisi Eksisting dan Persebaran Ekosistem Mangrove Berdasarkan Metode Penginderaan Jauh}

Penentuan kondisi ekosistem mangrove menggunakan metode penginderaan jauh ini menggunakan citra Google Earth tahun 2015. Keunggulan citra Google Earth jika dibandingkan dengan Landsat adalah memiliki tingkat akurasi yang lebih detail. Tingkat kedetailan yang cukup tinggi memudahkan peneliti dalam melakukan proses interpretasi dan membedakan antara mangrove dengan pohon-pohon yang lainnya.

Ekosistem mangrove ini terdapat di wilayah kepesisiran Kecamatan Pantai Labu menyebar sebagian mengikuti garis pantai dan sebagian ada yang terdapat di pinggir-pinggir sungai. Kecamatan Pantai Labu ini memiliki garis pantai sepanjang $14,77 \mathrm{~km}^{2}$ (Ginting, dkk, 2010). Garis pantai ini sifatnya dapat berubah-ubah karena adanya proses dinamika pantai.

Dinamika fisik wilayah kepesisiran yang terjadi di Kecamatan Pantai Labu ada 2 yaitu terjadi proses akresi dan proses erosi. Proses akresi ini terjadi di sekitar Delta Sungai di Desa Denai Kuala yang mengalami penambahan wilayah daratan. Proses erosi ini terjadi di sebagian kecil Desa Denai Kuala dan Desa Paluh Sebaji. Erosi atau pengikisan pantai akan menyebabkan berkurangnya areal daratan dan akan menyebabkan berubahnya garis pantai dari waktu ke waktu.

Berdasarkan hasil interpretasi citra Google Earth desa yang mempunyai luas ekosistem mangrove paling besar adalah Desa Denai Kuala, yaitu sebesar 187,79 ha. Desa yang mempunyai luas mangrove yang paling kecil adalah Desa Pantai Labu Pekan, dengan luas sekitar 15,85 ha. Luas ekosistem mangrove di Desa Paluh Sebaji berkisar 73,48 Ha, Desa Regemuk berkisar 
33,5 ha, Desa Bagan Serdang seluas 78,75 ha, dan Desa Sungai Tuan sebesar 128,58 ha. Kondisi eksisting ekosistem mangrove yang terdapat di Kecamatan Pantai Labu berdasarkan hasil interpretasi visual citra Google Earth Tahun 2015 totalnya sebesar 517,95 ha. Peta persebaran dan luas ekosistem mangrove pada masing-masing desa dapat dilihat secara jelas pada Gambar 1, Gambar 2 dan Tabel 1.

Persebaran dan agihan ekosistem mangrove di Kecamatan Pantai Labu berada di sepanjang tepi pesisir yang meliputi Desa Sungai Tuan, Desa Bagan Serdang, Desa Regemuk, Desa Pantai Labu Pekan, Desa Paluh Sebaji, dan Desa Denai Kuala.

Tabel 1. Luas Ekosistem Mangrove setiap desa di Wilayah Kepesisiran Pantai Labu

\begin{tabular}{|l|l|r|r|}
\hline No. & Keterangan & \multicolumn{1}{l|}{$\begin{array}{l}\text { Luas } \\
\text { (ha) }\end{array}$} & \multicolumn{2}{l|}{$\begin{array}{l}\text { Persentase } \\
\text { (\%) }\end{array}$} \\
\hline 1. & Desa Paluh Sebaji & 73,48 & 14,19 \\
\hline 2. & Desa Denai Kuala & 187,79 & 36,26 \\
\hline 3. & Desa Pantai Labu Pekan & 15,85 & 3,06 \\
\hline 4. & Desa Regemuk & 33,5 & 6,47 \\
\hline 5. & Desa Bagan Serdang & 78,75 & 15,20 \\
\hline 6. & Desa Sungai Tuan & 128,58 & 24,82 \\
\hline \multicolumn{2}{|r|}{ TOTAL } & 517,95 & 100,00 \\
\hline
\end{tabular}

Sumber: Hasil Interpretasi dan Analisis Tahun 2015

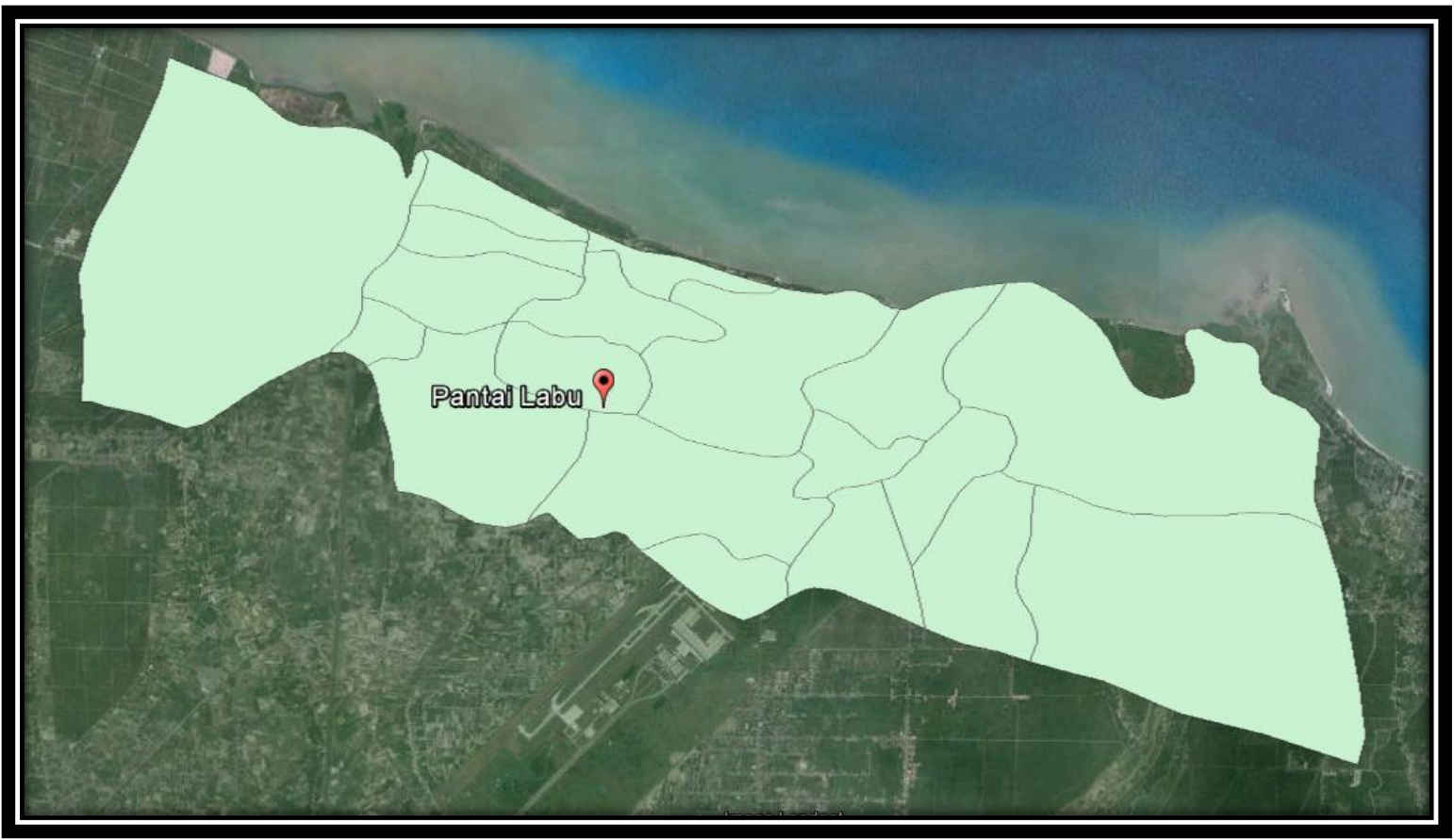

Gambar 2. Citra Google Earth Daerah Penelitian di Kecamatan Pantai Labu 


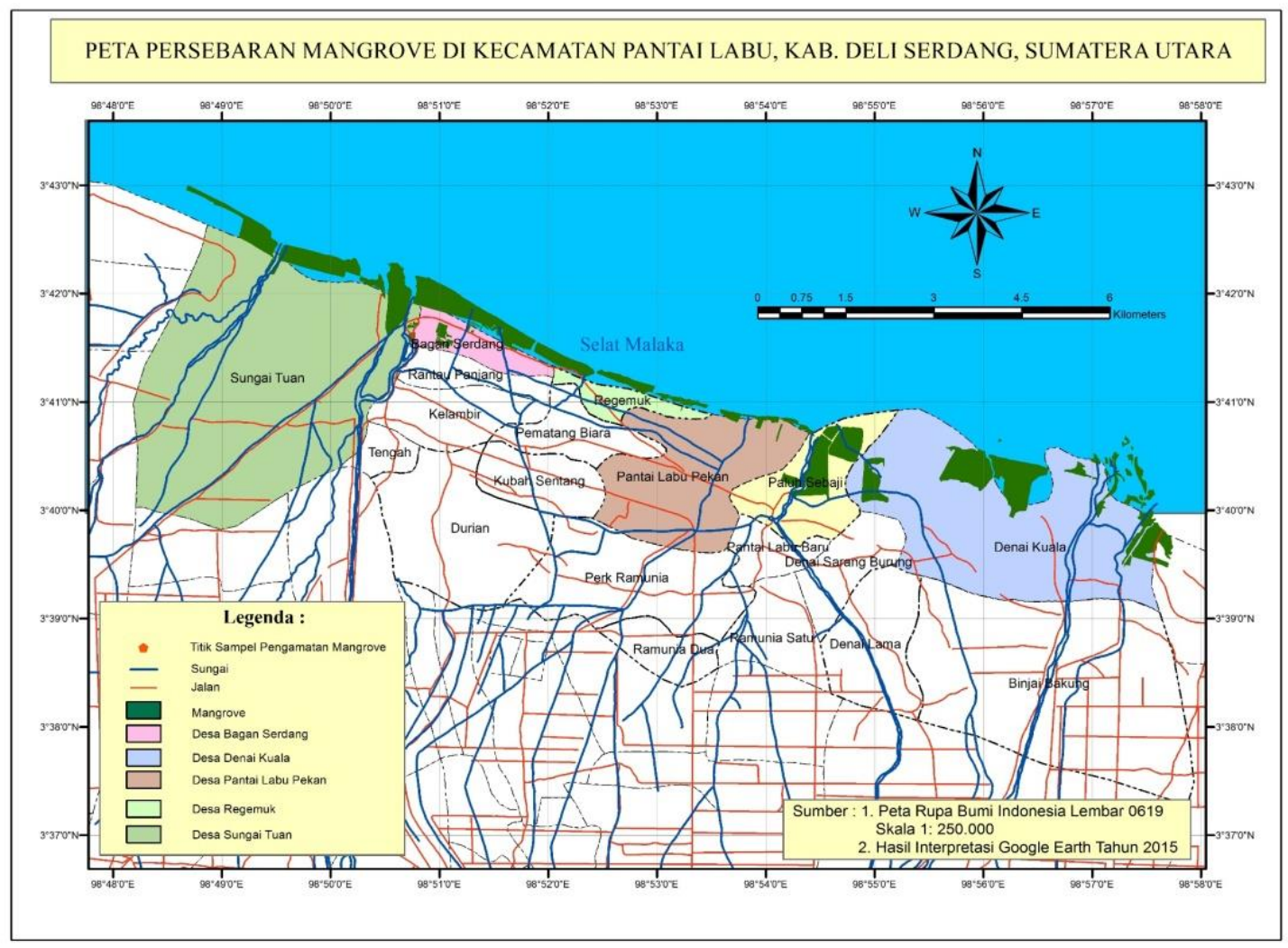

Gambar 2. Peta Persebaran Ekosistem Mangrove di wilayah kepesisiran Kecamatan Pantai Labu

\section{Kondisi Eksisting Ekosistem Mangrove Berdasarkan Metode Deskriptif}

Metode deskriptif ini digunakan untuk mengetahui kondisi eksisting mangrove berdasarkan spesiesnya. Spesies mangrove tidak dapat dilihat langsung dari data penginderaan jauh, sehingga diperlukan pengamatan dan perhitungan mangrove yang terdapat di lapangan.

Perhitungan dan analisis deskriptif ini digunakan untuk mendeskripsikan komunitas ekosistem mangrove yang terdapat di daerah penelitian yang meliputi kerapatan (densitas), kekerapan/frekuensi, luas penutupan (coverage), indeks nilai penting (importance value index), indeks dominasi (index of dominance), dan indeks keanekaragaman (diversity). Beberapa parameter yang harus dihitung di lapangan adalah pengamatan spesies dengan menggunakan buku pedoman jenis-jenis mangrove, jumlah pohon, diameter batang pohon jenis, dan lingkaran pohon setinggi dada. Perhitungan analisis deskriptif vegetasi ini dihitung berdasarkan tingkat pohon, tingkat pancang, dan tingkat semai.

Berdasarkan hasil observasi spesies mangrove yang mendominasi di Kawasan Konservasi Mangrove Kelompok Pantai Putra Deli terdiri dari spesies Avicennia sp (api-api), Rhizophora sp (bakau), Sonneratia $s p$ (pedada), dan Xylocerpus sp (nyirih). Spesies mangrove yang terdapat di daerah penelitian dapat di lihat pada Gambar 3 di bawah ini. 

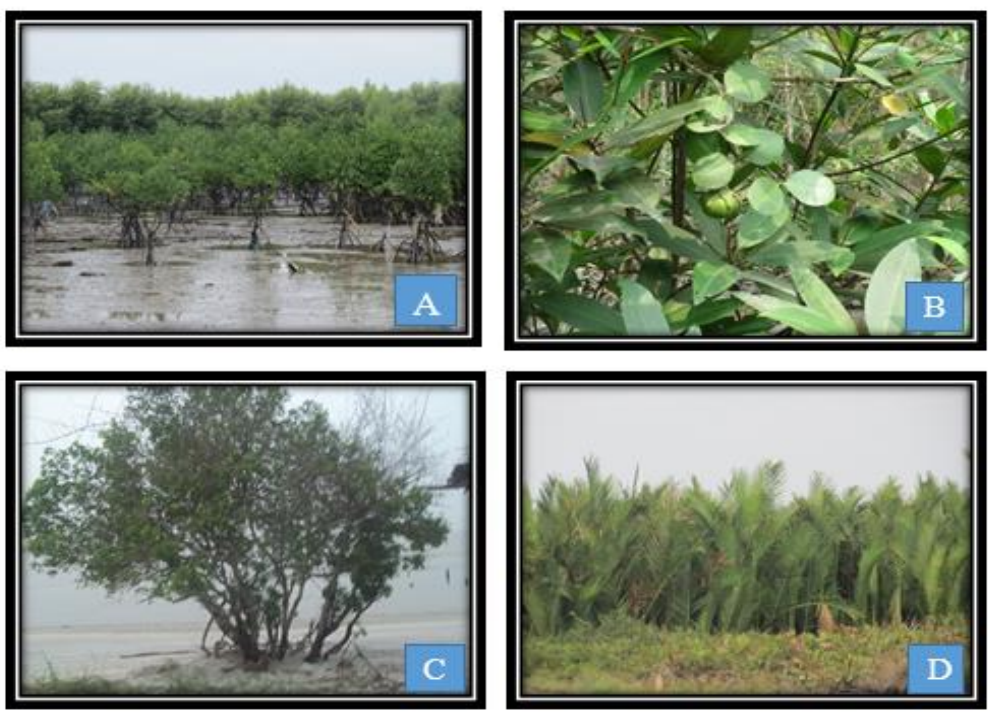

Gambar 3. Spesies Ekosistem Mangrove yang terdapat di Kecamatan Pantai Labu (A) Rhizophora sp (bakau), (B) Sonneratia sp (pedada), (C) Avicennia sp (api-api), dan (D) Xylocerpus sp (nyirih)

Indeks keanekaragaman spesies digunakan untuk mengetahui keanekaragaman spesies tumbuhan di suatu wilayah. Keanekaragaman atau keragaman (diversity) spesies merupakan ciri tingkat komunitas berdasarkan organisasi biologinya. Keanekaragaman spesies dapat digunakan untuk menyatakan struktur komunitas dan mengukur stabilitas komunitas, yaitu kemampuan suatu komunitas untuk menjaga dirinya tetap stabil meskipun ada gangguan terhadap komponenkomponennya (Soegianto, 1994 dalam Kordi, 2012).

Perhitungan

indeks keanekaragaman ini menggunakan formula Indeks Shannon (Shannon Index of General Diversity). Keanekaragman spesies yang tinggi menunjukkan bahwa suatu komunitas memiliki kompleksitas tinggi karena interaksi spesies. Suatu komunitas dikatakan memiliki keanekaragaman spesies yang tinggi jika komunitas itu disusun oleh banyak spesies. Sebaliknya, suatu komunitas dikatakan memiliki keanekaragaman spesies yang rendah jika komunitas itu disusun oleh sedikit spesies dan jika hanya ada sedikit spesies yang dominan (Indriyanto, 2006 dalam Kordi, 2012).

Berdasarkan hasil analisis dan perhitungan indeks keanekaragaman spesies ekosistem mangrove di Kecamatan Pantai Labu untuk tingkat pohon mempunyai indeks keanekaragaman sebesar 0,2256054, tingkat pancang mempunyai indeks keanekaragaman sebesar -0,8058752, dan tingkat semai mempunyai indeks keanekaragaman sebesar -0,5475611. Secara keseluruhan baik dari tingkat pohon, pancang, dan semai dapat disimpulkan bahwa keanekaragaman vegetasi mangrove di Kecamatan Pantai Labu memiliki indeks keanekaragaman $\mathrm{H}^{\prime}<1,0$. Artinya keanekaragaman mangrove di Kecamatan Pantai Labu masih rendah, miskin, produktivitas sangat rendah sebagai indikasi adanya tekanan yang berat, dan ekosistem tidak stabil. Rincian indeks keanekaragaman jenis mangrove di Kecamatan Pantai Labu dapat dilihat pada Tabel 2. 
Tabel 2. Indeks Keanekaragaman Mangrove di Kecamatan Pantai Labu

\begin{tabular}{|l|l|r|r|r|c|}
\hline No. & \multicolumn{1}{|c|}{ Ket } & ni/N & $\log (\mathrm{ni} / \mathrm{N})$ & $\begin{array}{c}(\mathrm{ni} / \mathrm{N}) \star \log \\
(\mathrm{ni} / \mathrm{N})\end{array}$ & $\mathrm{H}$ \\
\hline 1. & Tingkat Pohon & 1,00 & $-0,7738603$ & $-0,2256054$ & 0,2256054 \\
\hline 2. & Tingkat Pancang & 1,58 & 1,00 & 0,8058752 & $-0,8058752$ \\
\hline 3. & Tingkat Semai & 1,00 & 1,00 & 0,5475611 & $-0,5475611$ \\
\hline
\end{tabular}

Sumber: Hasil Analisis dan Perhitungan, 2015

\section{KESIMPULAN}

Berdasarkan hasil yang sudah dicapai dalam penelitian ini dapat disimpulkan bahwa:

1. Kondisi eksisting ekosistem mangrove yang terdapat di Kecamatan Pantai Labu berdasarkan hasil interpretasi visual citra Google Earth Tahun 2015 sebesar 517,95 ha.

2. Keanekaragaman vegetasi mangrove di Kecamatan Pantai Labu memiliki indeks keanekaragaman $\mathrm{H}^{\prime}<1,0$. Artinya keanekaragaman mangrove di Kecamatan Pantai Labu masih rendah, miskin, produktivitas sangat rendah sebagai indikasi adanya tekanan yang berat, dan ekosistem tidak stabil.

3. Persebaran dan agihan ekosistem mangrove di Kecamatan Pantai Labu berada di sepanjang tepi pesisir yang meliputi Desa Sungai Tuan, Desa Bagan Serdang, Desa Regemuk, Desa Pantai Labu Pekan, Desa Paluh Sebaji, dan Desa Denai Kuala.

\section{UCAPAN TERIMA KASIH}

Penulis mengucapkan terimakasih atas dukungan biaya dari Universitas Negeri Medan, Kementerian Pendidikan dan Kebudayaan Sesuai dengan Surat Perjanjian Penggunaan Dana (SP2D), Nomor: 126/UN33.8/KU/2015, tanggal 01 Juni 2015 yang telah membuat penelitian ini terlaksana. Ucapan terimakasih juga kami sampaikan kepada seluruh civitas akademisi Jurusan Pendidikan Geografi UNIMED.

\section{DAFTAR PUSTAKA}

Badan Pusat Statistik. (2014). Kabupaten Dei Serdang Dalam Angka 2014. Pemerintah Kabupaten Deli Serdang.
Ginting, C., Suharsono, T. W, Sari, N. (2010). Pengelolaan Sumberdaya Alam Pesisir Kecamatan Pantai Labu Dengan Pendekatan Partisipatif. Jurnal diakses tanggal 22 September 2015 jam 15.00.

Gunawan, T., Santosa, L. W., Muta'ali, L., Santosa, S. H. M. B. (2005). Pedoman Survei Cepat Terintegrasi Wilayah Kepesisiran. Fakultas Geografi: Universitas Gadjah Mada, Yogyakarta.

Khakhim, N. (2011), Bahan Ajar Pengelolaan Wilayah Pesisir. Fakultas Geografi: Universitas Gadjah Mada Yogyakarta.

Kordi, M. G. H. (2012). Ekosistem Mangrove Potensi, Fungsi, dan Pengelolaan. Jakarta: Rineka Cipta.

Peraturan Menteri Kehutanan No.P.03/MENHUT/-V/2004 tentang Pedoman dan Petunjuk Pelaksanaan Penyelenggaraan Gerakan Nasional Rehabilitasi Hutan dan Lahan.

Sunarto. (2003). Geomorfologi Pantai: Dinamika Pantai, Laboratorium Geomorfologi Terapan. Jurusan Geografi Fisik, Fakultas Geografi Universitas Gadjah Mada, Yogyakarta.

Van Zuidam, R.A. and Van ZuidamCancelado. (1978). Terrain Analysis and Classification Using Aerial Photographs: A Geomorfological Approach. ITC Textbook Vol.VII Ch.6, ITC, Enschede.

Yusnawati, C. (2004). Pengaruh Sosial Ekonomi Masyarakat Terhadap 
Pemanfaatan Hutan Mangrove di Kecamatan Pantai Labu Kabupaten Deli Serdang, Tesis. Pengelolaan Sumberdaya Alam dan Lingkungan Universitas Sumatera Utara, Medan. 